\title{
THE PECULIARITIES OF UKRAINIAN HEALTH WORKERS’ PROFESSIONAL BURNOUT
}

\author{
IRINA ASTREMSKA ${ }^{1}$ \\ ${ }^{1}$ An associate professor of the Department of Psychology of the Petro Mohyla Black Sea \\ National University, Mykolaiv (Ukraine) \\ ORCID ID: https://orcid.org/0000-0002-9746-3356
}

UDC: 159.944 .3

\section{SUMMARY}

The article examines the health workers' professional burnout manifestations. The results of the research on differences between doctors and nurses regarding the specifics of their professional burnout, their use of coping strategies, the qualities of emotional intelligence and communicative competence are described.

The sensitivity work periods for professional burnout formation at doctors and nurses, as well as differences in value orientations of the specified groups depending on deepness of their professional burnout are established. The comparison of the work experience and the burnout stages shows that the sensitivity work periods for burnout formation are 11 to 20 years of work for the doctors, and from 1 to 10 years of work for nurses (on the basis of professional experience comparison with the burnout stages).

Nurses generally have a slightly deeper professional burnout in comparison with doctors.

The only difference in the used coping strategies between the doctors and the nurses is that the doctors are more adaptable than the nurses; they more often use coping strategies for responsibility acceptance and positive reappraisal. The junior medical staff is more likely to experience burnout.

In general, nurses have lower emotional intelligence than doctors. As for correlations between the indicators demonstrating the dynamics of professional burnout and the structural elements of emotional intelligence, there are significant reliable negative correlations between the doctors' professional burnout and control over own emotions and self-motivation.

As for the studied nurses, there are the significant reliable negative correlations between professional burnout and such elements of professional intelligence as recognition of the emotions of others, empathy, and

Address for correspondence, e-mail : editpsychas@gmail.com

Copyright: (C) Irina Astremska

This is an Open Access journal, all articles are distributed under the terms of the Creative Commons AttributionNonCommercial-ShareAlike 4.0 International (CC BY-NC-SA 4.0) License (http://creativecommons.org/licenses/by-nc$\mathrm{sa} / 4.0 /$ ), allowing third parties to copy and redistribute the material in any medium or format and to remix, transform, and build upon the material, provided the original work is properly cited and states its license. 
control over their own emotions (the last indicator in corresponds with the results obtained for the doctors).

There is a tendency to increased use of the dependent communicative style by the doctors and the aggressive style by the nurses with the deepening of professional burnout.

The professional burnout deepening increases significance of the health value for the doctors, as well as decreases importance of professional growth for both the doctors and the nurses.

The techniques for psychological debriefing in the structure of the supervision method are proposed to overcome the problem of emotional burnout.

Key words: professional work, health workers, professional stress, professional burnout, coping strategy, supervision, psychological debriefing.

The study is relevant due to the fact that medical professionals face the problem of low resource potential of the national health system on a daily basis, which provokes the emergence of these specialists burnout on the background of a chronic stress state.

Health workers' work is highly stressful also due to large amount of communications, including the difficult nature of these communications, high responsibility and the inability in some cases to change the unfavourable course of things. The fact that health workers suffering from a burnout syndrome do not understand it and, therefore, are unable to help themselves independently, is also a dangerous factor.

Analysis of recent publications. The study of the problem of professional burnout was started by with J. Freidenberg, who introduced the notion of an occupational burnout syndrome and continued by a number of foreign scientists such as V. Boyko, J. Greenberg, S. Jackson, K. Maslach, B. Perlman, A. Hartmann, who laid the theoretical foundation for further applied re- search. Modern national psychologists $\mathrm{T}$. Zaichikova, L. Karamushka, O. Kinyev-Smyk, O. Solodukhova, T. Yatsenko explored the specifics of determination and the course of professional burnout in the Ukrainian professional environment.

The purpose of the article is to highlight and analyze the results of the empirical research on deepness of health workers' professional burnout, as well as its features characteristic for doctors and nurses.

Unresolved issues. Despite a large number of the existing works in the Ukrainian psychological science, there is no systematic comprehensive work devoted to the study of differences between doctors and the nurses regarding the features of their use of coping strategies, depending on the qualities of emotional intelligence and communicative competence, and deepness of their professional burnout. The research also has the practical value because that it proposes ways to overcome the specified problem, namely the use of techniques of psychological debriefing in 
the supervisory method.

\section{Presentation of the main research mate-}

rial. Professional burnout is a recognized phenomenon, since it is defined by WHO and is included into ICD-10. The study of the aforementioned phenomenon began in 1974 on the initiative of J. Freidenberg.

There is a large variety of definitions of this phenomenon, a rather broad interpretation; the limits of the term are constantly expanded in the modern psychological science. Western psychologists defined the main provisions for identifying a professional burnout syndrome in 1993 at the San Francisco Conference («Professional burnout: Recent developments in the theory and research», 1993).

In particular, the scientists agreed that:

the burnout syndrome has a threecomponent structure, which includes psychoemotional exhaustion, depersonalization (cynicism) and reduction of professional achievements;

burnout is a relatively irreversible phenomenon;

burnout is a general phenomenon, but is characteristic, first of all, to professionals working in the field of «helping» professions (Lavrova, 2014).

The structure adopted at the conference in San Francisco was proposed by K. Maslach (Maslach, 1994). She defines the professional burnout syndrome as a state of physical, emotional and mental exhaustion, which is characteristic mainly for the social professions. There are three main groups of its manifestation: emotional exhaustion, depersonalization (cynicism) and reduction of professional achievements (Sergienko \& Zhuravlev, 2011).

By analysing the foreign studies on emotional burnout, A. V. Kostiuk (Kostiuk, 2005) has concluded that «the main approaches are based on emphasizing the global discrepancy between the requirements imposed on the employee and his/her resources; mismatch between work and personality; discrepancy between the ethical principles, an individual's principles and the work requirements».

Burnout is traditionally considered in the national psychology as a special personal state, which is the result of professional stress and professional adaptation, but the problemic field of the emotional burnout studies has considerably expanded lately - through the existential approach, the phenomenon of mental health, etc.

This means that the psychological effects of emotional burnout can be manifested in various areas of personal life and not only in professional communications (Kostiuk, 2005) .

A. V. Kostiuk offers a structural model of the emotional burnout emergence, which includes the following factors: 1) socio-demographic (a position, children, etc.), 2) internel (general experience), 3) personal; 4) attitude to work and self (satisfaction from work, socially oriented and individually oriented attitudes, feeling of helplessness, disloyalty, addictive overcoming of anxiety, 
etc.) (Kostiuk, 2005) .

S. Nazarova (Nazarova, 2007) distinguishes the following models of mental burnout:

1. One-dimensional model includes physical and mental disorders caused by long-term overloads in professionally significant situations. This interpretation is close to chronic fatigue syndrome. Emotional exhaustion is manifested in devastation and chronic fatigue.

2. Burnout as a two-dimensional construct. It consists of emotional emptiness and depersonalization, which worsens and complicates relations with others (subordinates, colleagues, patients).

Depersonalization is manifested, on the one hand, in psychological dependence, and, on the other, in negativism, cynicism of attitudes and feelings; for example, in an indifferent and nonhumanistic attitude towards another person. The level of abuse, conflicts, sensitivity to criticism, deforming an individual's state, is increasing.

3. Three-component burnout model includes emotional exhaustion, depersonalization, reduction of personal responsibilities.

Psychological burnout can be interpreted as a professional crisis, associated with stress in work and interpersonal relationships.

The scientist (Nazarova, 2007) distinguishes the following burnout characteristics: 1) reduced background mood, combined with anxiety; 2) asthenia, constant fatigue, emotional exhaustion; 3) feeling of incompleteness, dissatisfaction at interactions; 4) psychosomatic reactions: sleep disorders, cardiovascular disorders, etc.; 5) short-term psychogenic reactions in the form of obsessive thoughts, phobias, doubts after complex emotionally-tense situations; 6) a changed attitude towards own professional work, reduced self-esteem, a feeling of professional and personal insolvency, a sense of senselessness of what is happening; 7) negative emotions in communications, the predominance of stereotypical skills, the formal fulfillment of duties, the refusal of creative productive activity.

Consequently, the phenomenon of burnout is manifested as a state of physical and mental exhaustion, caused by emotional strain at working with people.

The following individual factors influence the burnout of specialists: age, level of education, marital status, work experience, endurance, locus of control, style of resistance, self-esteem, neuroticism (anxiety), extraversion. The following organizational factors also influence: working conditions, work overload, time deficit, duration of working day, content of work, number of clients and the severity of their problems and the depth of contact with them, participation in decisionmaking, feedback (Nazarova, 2007) .

Now, professional burnout models are divided into two groups, based on various theories: factorial (description of the burnout structure and components) and procedural (burnout as a dynamic process with phases).

However, M. G. Lavrova emphasizes the importance of taking into account both sides of this phenomenon. She explains this by the fact that the burnout structural components are formed 
in the dynamic process, but revealed in the study of professional burnout. This thesis is recognition of the presence of both modalities in the phenomenon of professional burnout at the same time its structure and process. This is understanding of the psychic phenomenon of burning as procedural (dynamic manifestations in time, stage) and, at the same time, structural (certain stable forms) (Lavrova, 2014).

55 people aged 20-76 - doctors and nurses from the Mykolayiv Regional Children's Clinical Hospital were studied experimentally to determine the specifics of health workers' professional burnout.

A number of diagnostic techniques were used, such as: Boyko's technique «Diagnosis of emotional burnout», R. Lazarus' questionnaire «Methods of Captive Behavior», Hall's technique without professional burnout, 12 (42.8\%) persons with symptoms of the process of burnout formation, and 8 (28.6\%) of those with the already formed burnout syndrome.

There were 7 (25.9\%) nurses without symptoms of burnout, $10(37.05 \%)$ persons with burnout at the stage of formation, and 22 specialists with formed professional burnout. Summary data are presented in Table 1.

This table clearly shows that the nurses have slightly deeper professional burnout in comparison with that of the doctors. A detailed analysis of the most common symptoms of professional burnout has shown that the respondents in the both groups have mainly:

inadequate emotional response $(78.5 \%$ of doctors, $77.7 \%$ of nurses);

lower attitudes to professional responsibil-

Table 1. The distribution of the studied doctors and nurses, depending on their professional burnout deepness

\begin{tabular}{|l|c|c|c|}
\hline \multirow{2}{*}{ Position } & \multicolumn{3}{|c|}{ The deepness of professional burnout formation } \\
\cline { 2 - 4 } & $\begin{array}{c}\text { without professional } \\
\text { burnout }\end{array}$ & $\begin{array}{c}\text { in the process of for- } \\
\text { mation }\end{array}$ & formed burnout \\
\hline Doctors (28) & 8 & 12 & 8 \\
\hline Nurses (27) & 7 & 10 & 10 \\
\hline Total(55) & 15 & 22 & 18 \\
\hline
\end{tabular}

for emotional intelligence diagnosing, Michelson's communicative skills test (in adaptation of $\mathrm{Yu}$. Hilbuh), the questionnaire on the general information about medical sphere of the studied specialists.

The respondents were divided into several groups by using Boyko's technique «Diagnosis of emotional burnout»: there were $8(28.6 \%)$ doctors ities (66.7\% and 59.2\%, respectively), emotional and moral disorientation (57.1\% and 59.2\%, respectively).

However, the difference is that doctors are more likely to experience the expansion of the saving emotion sphere (53.5\%), and the nurses have emotional deficits (55.5\%).

The professional burnout symptoms mani- 
fested by the studied doctors and nurses are quite similar. But some of the symptoms are graver at nurses.

We investigated the use of coping strategies by the doctors and nurses on the background of the burnout phenomenon. There is only one difference in coping strategies used by the studied doctors and nurses: doctors use coping strategies for accepting responsibility and positive reassessment more adaptively than nurses. In the context of the previously reported data, this fact indicates syndrome (Table 2).

Thus, there is a general tendency of health workers' emotional intelligence decrease with increase of the burnout deepness.

In general, nurses have lower emotional intelligence than doctors. By comparing the average level of the respondents' emotional intelligence, we have found that the nurses have lower emotional intelligence and lower resistance to professional burnout than the doctors, which can be due to the specifics of their professional du-

Table 2. The doctors' and nurses' total emotional intelligence (depending on their professional burnout)

\begin{tabular}{|c|c|c|c|}
\hline \multirow{2}{*}{ Position } & \multicolumn{3}{|c|}{ Total level of emotional intelligence (average score) } \\
\cline { 2 - 4 } & $\begin{array}{c}\text { without professional } \\
\text { burnout }\end{array}$ & $\begin{array}{c}\text { in the process of for- } \\
\text { mation }\end{array}$ & formed burnout \\
\hline Doctors (28) & 53,4 & 51,5 & 34,0 \\
\hline Nurses (27) & 39,9 & 38,6 & 22,5 \\
\hline Difference & 13,5 & 12,9 & 18 \\
\hline
\end{tabular}

that the nursing staff experience professional ties.

burnout more often.

The total level of emotional intelligence and its correlation with the burnout deepness was determined to establish a correlation of the emotional intelligence with the respondents' burnout
The correlation analysis for emotional intelligence indicators and burnout stages has been done after the performed general analysis.

The correlations between the examined indicators for the doctors are presented in the Ta-

Table 3. Correlation between professional burnout stages and emotional intelligence for doctors

\begin{tabular}{|c|c|c|c|c|c|c|}
\hline \multirow[t]{2}{*}{ Burnout phases } & \multicolumn{6}{|c|}{ Indicators of emotional intelligence } \\
\hline & $\begin{array}{l}\text { Emotional } \\
\text { awareness }\end{array}$ & $\begin{array}{c}\text { Control } \\
\text { over own } \\
\text { emotions }\end{array}$ & $\begin{array}{l}\text { Self- } \\
\text { motiva- } \\
\text { tion }\end{array}$ & Empathy & $\begin{array}{l}\text { Recogni- } \\
\text { tion of } \\
\text { emotions } \\
\text { of others }\end{array}$ & $\begin{array}{c}\text { Total } \\
\text { emotional } \\
\text { intelli- } \\
\text { gence }\end{array}$ \\
\hline Psychological tension & 0,035 & $-0,632 * *$ & $0,474 *$ & 0,098 & 0,374 & $-0,488 * *$ \\
\hline Resistance & 0,044 & $-0,574 * *$ & $0,549 * *$ & 0,373 & 0,355 & $-0,526 * *$ \\
\hline Exhaustion & 1,176 & $-0,419 *$ & 0,205 & 0,070 & 0,172 & $-0,232$ \\
\hline
\end{tabular}


ble 3; they demonstrate the dynamic side of professional burnout.

The data in the table shows the significant reliable negative correlations between the doctors' professional burnout and such indicators of their emotional intelligence as control over their own emotions and self-motivation. duties: doctors make decisions, and nurses only implement them.

The general tendency to less often use of the competent communicative style with the increase of professional burnout deepness is tracked for the both groups. At the same time, with deepened professional burnout, doctors use more often

Table 4. Correlation Correlations between professional burnout stages and emotional intelligence for nurses

\begin{tabular}{|c|c|c|c|c|c|c|}
\hline \multirow{2}{*}{ Burnout phases } & \multicolumn{6}{|c|}{ Indicators of emotional intelligence } \\
\cline { 2 - 7 } & $\begin{array}{c}\text { Emotional } \\
\text { awareness }\end{array}$ & $\begin{array}{c}\text { Control } \\
\text { over own } \\
\text { emotions }\end{array}$ & $\begin{array}{c}\text { Self- } \\
\text { motiva- } \\
\text { tion }\end{array}$ & Empathy & $\begin{array}{c}\text { Recognition } \\
\text { of emotions } \\
\text { of others }\end{array}$ & $\begin{array}{c}\text { Total emo- } \\
\text { tional in- } \\
\text { telligence }\end{array}$ \\
\hline $\begin{array}{c}\text { Psychological ten- } \\
\text { sion }\end{array}$ & $0,244^{-}$ & $0,337^{-}$ & $0,223^{-}$ & $0,372^{-}$ & $0,574^{* * *}$ & $0,469^{*}$ \\
\hline Resistance & $0,228^{-}$ & $0,387^{*}$ & $0,322^{-}$ & $0,405^{* *}$ & $0,469^{*}$ & $0,533^{* *}$ \\
\hline Exhaustion & $0,228^{-}$ & $0,332^{-}$ & $0,292^{-}$ & $0,223^{-}$ & $0,565^{* *}$ & $0,446^{*}$ \\
\hline
\end{tabular}

As for nurses, there are some other correlations for the examined indicators (Table 4).

As for the studied nurses, there are the significant reliable negative correlations between professional burnout and such elements of professional intelligence as recognition of the emotions of others, empathy, and control over their own emotions (the last indicator in corresponds with the results obtained for the doctors).

The data obtained with Michelson's communicative skills test (in adaptation of Yu. Hilbuh) have led us to the following conclusion: the nurses show the dependent type of responses in communicative situations more often than doctors. Probably this is due to their official the dependent communicative style, but nurses use the aggressive one.

The study of the doctors' value orientation shows that such values as patient's health and their own health are always at the first place, regardless of professional burnout deepness. But the value of their own health is becoming more important with burnout aggravation. Salary is more important for doctors and acceptable working conditions are more important for nurses; the importance of professional growth decreases in both professional groups with deepened burnout.

We have also found that the sensitizing period for burnout formation is the period of 11 to 20 years of work for doctors, and from 1 to 10 
years of work for nurses (by comparing the respondents' period of work and the deepness of their professional burnout).

S. Nazarova (Nazarova, 2007), considers it expedient to take into account all emotional burnout factors and proposes to apply a systematic approach to prevent the emotional burnout by organisation of professional communities, groups with organized support of specialists. Specialists' work can be supervised within such groups.

Supervision means a collaboration of two or more professionals (more experienced and less experienced or equal in experience), during which they discuss work of one of the participants in complete confidence. It is a practical method for improvement of specialists' skills, allowing supervisors to understand and analyze their professional actions and behaviour. During the supervision, the group participants exchange knowledge, emotional experiences, reflexive experience, and their ways of response to difficult situations (Astremska, 2017).

Supervision is not a tool to control professional activities, but is a learning tool through discussion on a variety of issues. We can distinguish the main ones: 1) problems of selfunderstanding and self-perception; 2) theoretical knowledge and professional actions, interdependent development of theoretical knowledge and practical techniques (awareness why theoretical, practical skills are used or not used, how personal traits and attitudes determine a professional position); 3) relations with other people (the group participants); 4) the organizational issues of practical work (relations with the administration and colleagues); 5) relations with the patients (problems of separation, isolation, dependence and other aspects of professional work) (Nazarova, 2007).

According to I.V. Ushakova (Ushakova, 2011), a supervisor's response to a specialist involved into work with the professional burnout problem should be viewed either as mediation or as reinforcement. Mediation includes supervisor's actions outside supervisory sessions - in a wider system, whereas reinforcement means responses arisen during supervisory sessions.

Mediation. Immediately after a request for work with emotional burnout, the supervisor should act an administrator, to ensure that the victim received appropriate medical support and necessary advice. The supervisor should resolve such practical cases as replacing of the traumatised employee, appointment cancelling, or redistribution of patients. The supervisor assumes the role of a lawyer (a negotiator) at contact with the police, judges or the media (if the situation requires it)

Reinforcement. Given the upcoming work with the supervised, the supervisor's (and others') attitude to the specialist's condition is decisive. The supervised specialist is likely to be in a sensitized state, unable to uncritically react. There is a high probability of his/her unprofessional behaviour, therefore the specialist should and must be supervised. 
At the last stage of professional burnout, when there are somatic symptoms, depression, powerful emotional exhaustion, the suffering professionals have different emotional needs: some want to discuss own condition; others, first of all, need to obtain feeling that control has been regained. The supervisor must be sensitive to the difference in needs and not be biased towards them.

Supervisors should use psychological debriefing (surveys, inquiries conducted immediately after the request for dealing with the professional burnout problem) and seek help from a consultant experienced in using a debriefing technique.

Psychological debriefing is a preventive strategy used to minimize the probability of professional burnout symptoms: returns of traumatic experiences, nightmares, restless awakening, excessive caution, avoidance and phobias, psychogenic amnesia, etc. The debriefing techniques for group work are well described in the corresponding psychological literature.

In the framework of supervision, individual debriefing can be performed with various used methods and techniques, but within the following framework:

1. The supervised should be explained that telling about his/her state in the smallest details is necessary, but it can sometimes be very painful.

2. The supervised should be also explained that certain parts of the description of condition, situation can be hidden and appear on- ly in unwanted experiences and nightmares. Discussion of the smallest details can reduce involuntary returns to the most painful parts of the experience.

3. The supervised specialist should be asked, after his/her consent, to tell his/her history, from the moment when he/she anticipated the problem. The history should be told in the chronological order and attention should be paid all remembered emotions, feelings, thoughts, perceptions.

4. If the supervised starts to cry at some point, the supervisor should not cry with him/her, but, being aware of the specialist's stress state, propose to have a rest and continue later to be able to get rid of the negative experience. It is useful to ask what exactly caused difficulties and to express the feelings in words.

5. At each stage, the supervised person should be asked to recall the accompanying sounds, smells, flavours, colours and images. Such details are important because they stimulate a more selective and refined "launch" of memories that are the most emotionally tense, injurious, reducing the likelihood of negative memories by appearance of more vivid stimulus.

6. The supervisor must be sure that the supervised person talks not only about real feelings, but also what his/her thoughts about it. This can be even more anxious, exciting than the actual course of events.

7. The supervised person should never be asked to interpret or evaluate his/her actions; nei- 
ther the supervisor should give his/her attitudes or estimations. At this stage, the supervisor does not give advices, only finds out what the supervised feels about what's happening. The things to learn from this case are discusses later.

8. The information is collected about everything up to the current moment (with the smallest details).

9. After completing the story about the emotional condition and the situations that are most emotionally strained, the supervised specialist's feelings about the session should be discussed.

10. The supervisor should ask whether the supervised person had any other emotionally difficult situations and ease any stressful reactions. Precautionary guidelines for typical stress reactions and situations of emotional burden, discomfort should be proposed later.

11. The supervised person should be proposed to evaluate the usefulness of the supervising counselling.

12. Conclusions should be made about further work.

Debriefing is usually carried out in a safe, secure place. It is necessary to allocate a lot of time for it. Debriefing is rarely used on time, at the first stage of the professional burnout development. Often conflicts, crises, etc., are the signs of the last stage of professional burnout and, consequently, the needs debriefing. Debriefing is often not organized until an individual reaches the crisis or some event reveals an existing trau- ma.

When the supervised specialist begins to adapt to the professional stress, the supervisor can:

- help him/her graphically illustrate the (emotional) professional stress impact on all aspects of professional work;

- help him/her understand such impacts;

- encourage expressing of feelings in relation to everything that happens to him/her and causes tension, stress;

- help him/her identify changes in him/ herself and in the world;

- assist him/her in the consideration of the faced emotional and professional problems and their priority determination;

- offer independent consultations (Ushakova, 2011).

\section{Conclusions and perspectives of further}

research. The analysed theoretical scientific sources have shown the gravity of the problem of health worker's professional burnout and the necessity to prevent or correct this negative syndrome. The research results show that professional burnout is more pronounced at the nurses than that at the doctors.

The nurses also use less adaptive coping strategies as for responsibility acceptance and positive reappraisal. The junior medical staff also has a lower level of emotional intelligence in general. There is a tendency to increased use of the dependent communicative style by the doctors and the aggressive style by the nurses with the 
deepening of professional burnout (based on the communicative skill study). The sensitivity work periods for burnout formation are 11 to 20 years of work for the doctors and from 1 to 10 years of work for the nurses (on the basis of professional experience comparison with the burnout stages).

Significance of the health value for the doctors increases with their professional burnout deepening, as well as importance of professional growth for both the doctors and the nurses decreases.

The prospects for further research are seen in the more detailed study of the influence of personal characteristics (gender, age, an experience of professional development crises, etc.) on the peculiarities of health workers' professional burnout.

\section{References (Transliteration):}

Astremska, I.V. (2017). Prykladni metodyky ta osnovy supervizii sotsialnoi roboty [Applied methods and foundations of social work supervision]. Mykolaiv: Vyd-vo ChDU im. Petra Mohyly [in Ukrainian].

Kostiuk, A.V. (2005). Psykholohichni osoblyvosti emotsiinoho vyhorannia operatyvnykh psykholohiv [Psychological features of operational psychologists`emotional burnout]. Candidate's thesis. Kyiv [in Ukrainian].

Lavrova, M.H. (2014). Teoretychnyi analiz suchasnykh pohliadiv na poniattia "emotsiine vyhorannia" [Theoretical analysis of the modern views on the concept of "emotional burnout"]. Visnyk Odeskoho natsionalnoho universytetu. Psykholo- hiia - Bulletin of the Odessa National University, Vols. 19, 2, 194-202 [in Ukrainian].

Nazarova, S. (2007). Superviziia kak sredstvo predotvrashcheniia professionalnoi deformatsii spetsialistov [Supervision as a means to prevent specialists` professional deformation]. Sotsialnaia pedagogika - Social pedagogy, 2, 115-120 [in Russian].

Sergienko, E.A., \& Zhuravlev, A.L. (Ed.). (2011). Stress, vygoranie, sovladanie $v$ sovremennom kontekste [Stress, burnout, coping in a modern context]. Moskva: «Institut psikhologii RAN» [in Russian].

Ushakova, I.V. (2011). Superviziia [Supervision]. Mykolaiv: Vyd-vo ChDU im. Petra Mohyly [in Ukrainian].

Maslach C. Burned-outcopsand their families / C. Maslach, S. E. Jackson // Psychologytoday. - 1994. - №5. P. 60 .

\section{Астремська Ірина Володимирівна}

Дочент кафедри психології Чорноморського начіонального університету імені Петра Могили, м. Миколаїв (Украӥна)

\section{СПЕЦИФІКА ПРОФЕСІЙНОГО ВИГОРАННЯ ПРАЦІВНИКІВ СФЕРИ ОХОРОНИ ЗДОРОВ'Я В УКРАЇНІ}

Анотація. В статті розглянуто особливості прояву професійного вигорання у медичних працівників. Висвітлено результати дослідження відмінностей лікарів та медсестр щодо особливостей використання ними копінг-стратегій, якостей емоційного інтелекту та комунікативної компетентності, залежно від ступеню вираженості професійного вигорання. 
Виявлено наявність сенситивності певного стажу роботи для формування професійного вигорання у лікарів та медсестр, а також відмінності ціннісних орієнтацій в зазначених групах в залежності від рівня професійного вигорання.

На підгрунті співставлення фахового стажу та фаз вигорання констатовано його сенситивність для формування вигорання, зокрема у лікарів це стаж від 11 до 20 років, а у медсестр - від 1 до 10 років.

Медсестри, на відміну від лікарів, в цілому мають дещо вищий рівень сформованості професійного вигорання.

Єдиною відмінністю у варіантах використання копінг-стратегій серед вибірки лікарів та медсестр є те, що лікарі більш адаптивніше, ніж медсестери, використовують копінгстратегії прийняття відповідальності та позитивної переоцінки. Саме молодший медичний персонал сильніше переживає професійне вигорання.

Встановлено, що в цілому у медсестр нижчий рівень емоційного інтелекту, ніж у лікарів. Встановлено зв'язок між шкалами, що демонструють динамічну сторону професійного вигорання, та рівнем емоційного інтелекту і його структурних елементів. Доведено снування суттєвого достовірного зворотного зв'язку між професійним вигоранням лікарів та такими елементами їх емоційного інтелекту, як управління своїми емоціями та самомотивація.
Показово, що у медсестр спостерігається зворотній зв'язок між професійним вигоранням та такими елементами професійного інтелекту, як розпізнавання емоцій інших людей, емпатія, а також (як і у лікарів) управління своїми емоціями.

Встановлено тенденцію до збільшення залежного стилю спілкування у лікарів та агресивного стилю у медсестр зі збільшенням професійного вигорання.

Засвідчено, що зростання рівня професійного вигорання провокує посилення цінності власного здоров'я медиків, а також зниження значення професійного зростання в обох професійних групах.

Запропоновано використання в структурі методу супервізії технік психологічного дебрифінгу для подолання проблеми емоційного вигорання.

Ключові слова: професійна діяльність, медичні працівники, професійний стрес, професійне вигорання, копінг-стратегія, супервізія, психологічний дебрифінг. 


\section{Астремская Ирина Владимировна}

Доцчент кафедры психологии Черноморского национального университета имени Петра Могиль, г. Николаев (Украина)

\section{СПЕЦИФИКА ПРОФЕССИОНАЛЬНОГО ВИГОРАНИЯ РАБОТНИКОВ СФЕРЫ ЗДРАВООХРАНЕНИЯ В УКРАИНЕ}

Аннотация. В статье рассмотрены особенности проявления профессионального выгорания у медицинских работников. Представлены результаты исследования различий врачей и медсестер об особенностях использования ими копинг-стратегий, качеств эмоционального интеллекта и коммуникативной компетентности, в зависимости от степени выраженности профессионального выгорания.

Выявлено наличие сенситивности определенного стажа работы для формирования профессионального выгорания у врачей и медсестер, а также различия ценностных ориентаций в указанных группах в зависимости от уровня профессионального выгорания.

На основе сопоставления профессионального стажа и фаз выгорания констатировано его сенситивнисть для формирования выгорания, в частности у врачей это стаж от 11 до 20 лет, а у медсестер - от 1 до 10 лет.

Медсестры, в отличие от врачей, в целом имеют несколько более высокий уровень сформированности профессионального выгорания.

Единственным отличием в вариантах использования копинг-стратегий среди выбор- ки врачей и медсестер является то, что врачи более адаптивнише, чем медсестер, используют копинг-стратегии принятия ответственности и положительной переоценки. Именно младший медицинский персонал сильнее переживает профессиональное выгорание.

Установлено, что в целом у медсестер низкий уровень эмоционального интеллекта, чем у врачей. Установлена связь между шкалами, демонстрирующая динамическую сторону профессионального выгорания, и уровнем эмоционального интеллекта и его структурных элементов. Доказано существование достоверной обратной связи между профессиональным выгоранием врачей и такими элементами их эмоционального интеллекта, как управление своими эмоциями и самомотивацией.

Показательно, что в медсестер наблюдается обратная связь между профессиональным выгоранием и такими элементами профессионального интеллекта, как распознавание эмоций других людей, эмпатия, а также (как и у врачей) управление своими эмоциями.

Установлена тенденция к увеличению зависимого стиля общения у врачей и агрессивного стиля у медсестер с увеличением профессионального выгорания.

Засвидетельствовано, что рост уровня профессионального выгорания провоцирует усиление ценности собственного здоровья медиков, а также снижение значения профессио- 
нального роста в обеих профессиональных группах.

Предложено использование в структуре метода супервизии техник психологического дебрифинга для решения проблемы эмоционального выгорания.

Ключевые слова: профессиональная деятельность, медицинские работники, профессиональный стресс, профессиональное выгорание, копинг-стратегия, супервизия, психологический дебрифинг. 